\title{
Pulmonary granulomas of guinea pigs induced by inhalation exposure of heat-treated BCG Pasteur, purified trehalose dimycolate and methyl ketomycolate
}

\author{
I. SUGAWARA, T. UDAGAWA, S. C. HUA, M. REZA-GHOLIZADEH, K. OTOMO, Y. SAITO* \\ and H. YAMADA
}

Department of Molecular Pathology, Research Institute of Tuberculosis, Japan Anti-Tuberculosis Association, 3-1-24 Matsuyama, Kiyose, Tokyo 204-0022, and*4th Department of Internal Medicine, Nippon Medical

School, Sendagi, Bunkyo-ku, Tokyo 113-8603, Japan

\begin{abstract}
This study was designed to determine the identity of granulomatogenic substances in Mycobacterium bovis BCG Pasteur. When heat-treated BCG Pasteur bacilli were introduced into the lungs of guinea-pigs by an inhalation exposure apparatus, pulmonary granulomas without necrosis developed. Furthermore, when four kinds of mycolates derived from $M$. tuberculosis Aoyama B strain were introduced into the lungs by the same method, only trehalose 6,6'-dimycolate (TDM) and methyl ketomycolate induced pulmonary granulomas without central necrosis. The pulmonary granulomas consisted of epithelioid macrophages and lymphocytes. When a mixture of TDM and anti-TDM antibody was introduced into the lungs, development of granulomatous lesions was reduced. These data indicate that TDM and methyl ketomycolate are potent granulomatogenic reagents.
\end{abstract}

\section{Introduction}

Chronic mycobacterial infection is characterised by granuloma formation with central caseous necrosis [1]. It is known that trehalose 6,6'-dimycolate (TDM; cord factor) derived from Mycobacterium tuberculosis induces granulomas when injected intravenously in adjuvant preparations [2-6]. As human mycobacterial granulomas are induced by an airborne route, it is meaningful to examine whether granulomas can be induced in experimental animals by this route. Also, there are many mycolic acid derivatives in the cell walls of mycobacteria and it is important to find other substances with granulomatogenic activity to understand the pathogenesis of tuberculosis.

An inhalation exposure system was established previously to induce pulmonary granulomas efficiently [7-9]. The present experiments with this system were designed to examine whether killed mycobacteria and TDM could induce granulomas aerially. At the same

Received 2 April 2001; revised version accepted 27 July 2001.

Corresponding author: Dr I. Sugawara (sugawara@ jata.or.jp). time, the granuloma-forming activity of mycolic acid derivatives other than TDM was also examined.

\section{Materials and methods}

\section{Animals}

Hartley female guinea-pigs (6-week-old) were purchased from Nippon SLC, Hamamatsu, Japan. They were kept in sterile, filter-topped cages and given sterile food and sterile, distilled water in a specific pathogen-free room.

\section{Mycobacterial strain and reagents}

M. bovis BCG Pasteur bacilli (ATCC 27289) were grown in $7 \mathrm{H} 9$ medium (Difco) to mid-log phase. They were then heat-treated at $95^{\circ} \mathrm{C}$ for $30 \mathrm{~min}$ in doubledistilled water and autoclaved at $121^{\circ} \mathrm{C}$ for $30 \mathrm{~min}$; then the treated strain was filtered with a $4-\mu \mathrm{m}$ poresize membrane filter (Millipore) before use to ensure even dispersal. TDM, methyl methoxymycolate methyl ketomycolate and methyl $\alpha$-mycolate were purchased from Nacalai Tesque, Kyoto, Japan. They were extracted from M. tuberculosis Aoyama B strain with chloroform/methanol and developed on a thin-layer 
plate of silica gel (Analtech, Newark, DE, USA) with the solvent system of chloroform/methanol/acetone/ acetic acid. Each was recovered with chloroform/ methanol, and the purification was repeated until a single spot was achieved by thin-layer chromatography. The structures of the four mycolates are illustrated in Fig. 1.

Rabbit anti-TDM polyclonal antibody was supplied by Nacalai Tesque. The anti-TDM antibody was generated by immunising New Zealand White rabbits five times with purified TDM in Freund's adjuvant.

\section{Inhalation exposure experiments}

Guinea-pigs were exposed to heat-treated BCG Pasteur autoclaved BCG Pasteur or mycolic acid derivative suspensions aerially by placing them in the exposure chamber of an inhalation exposure apparatus (Model 099CA4212; Glas-Col, Terre Haute, IN, USA). Five guinea-pigs were used for each treatment with BCG and three for each mycolic acid treatment. The nebuliser compartment was filled with $5 \mathrm{ml}$ of a suspension containing $10^{7}$ dead BCG Pasteur organisms or $1-5 \mathrm{mg}$ of mycolic acid derivatives. In several experiments, $1 \mathrm{mg}$ of rabbit anti-TDM polyclonal antibody was added to $1 \mathrm{mg}$ of TDM $30 \mathrm{~min}$ before inhalation exposure.

\section{Histopathology}

All guinea-pigs were killed 7 weeks after the inhalation exposure experiments. For light microscopy, sections cut from paraffin blocks containing lung, liver, lymph nodes and spleen tissues from the guinea-pigs were stained with haematoxylin and eosin. For electron microscopy, fresh lung tissue was cut into pieces, fixed with glutaraldehyde $2.5 \%$, post-fixed with osmium tetroxide $1 \%$, and embedded in Spurr's low-viscosity embedding medium $[9,10]$.

\section{Immunohistochemistry}

Immunohistochemistry was performed with avidinbiotin complex (ABC) peroxidase (PO) [11, 12]. Anti-M. bovis BCG antibody (Dakopatts, Copenhagen, Denmark) was used at a final concentration of $0.1 \mu \mathrm{g} / \mathrm{ml}$. This antibody recognises cell wall components of $M$. bovis. Lung tissue infected with live BCG was used as a positive control.

\section{DNA extraction and $P C R$}

PCR was used to evaluate the degree of DNA destruction by heat treatment and autoclaving. $M$. bovis BCG Pasteur was boiled and then autoclaved in double-distlled water and the DNA was purified with a Nucleon II DNA extraction kit (Scotlab, Coatbridge, Scotland) $[11,13]$. DNA was similarly extracted from pulmonary lesions. Whitish nodular lesions of the lung were obtained for DNA extraction [11].

Primers corresponding to portions of the M. tuberculosis IS6110 and 19-kDa antigen DNA sequences were synthesised on a 381 DNA synthesiser (Perkin-Elmer Cetus, Norwalk, CT, USA). The samples were

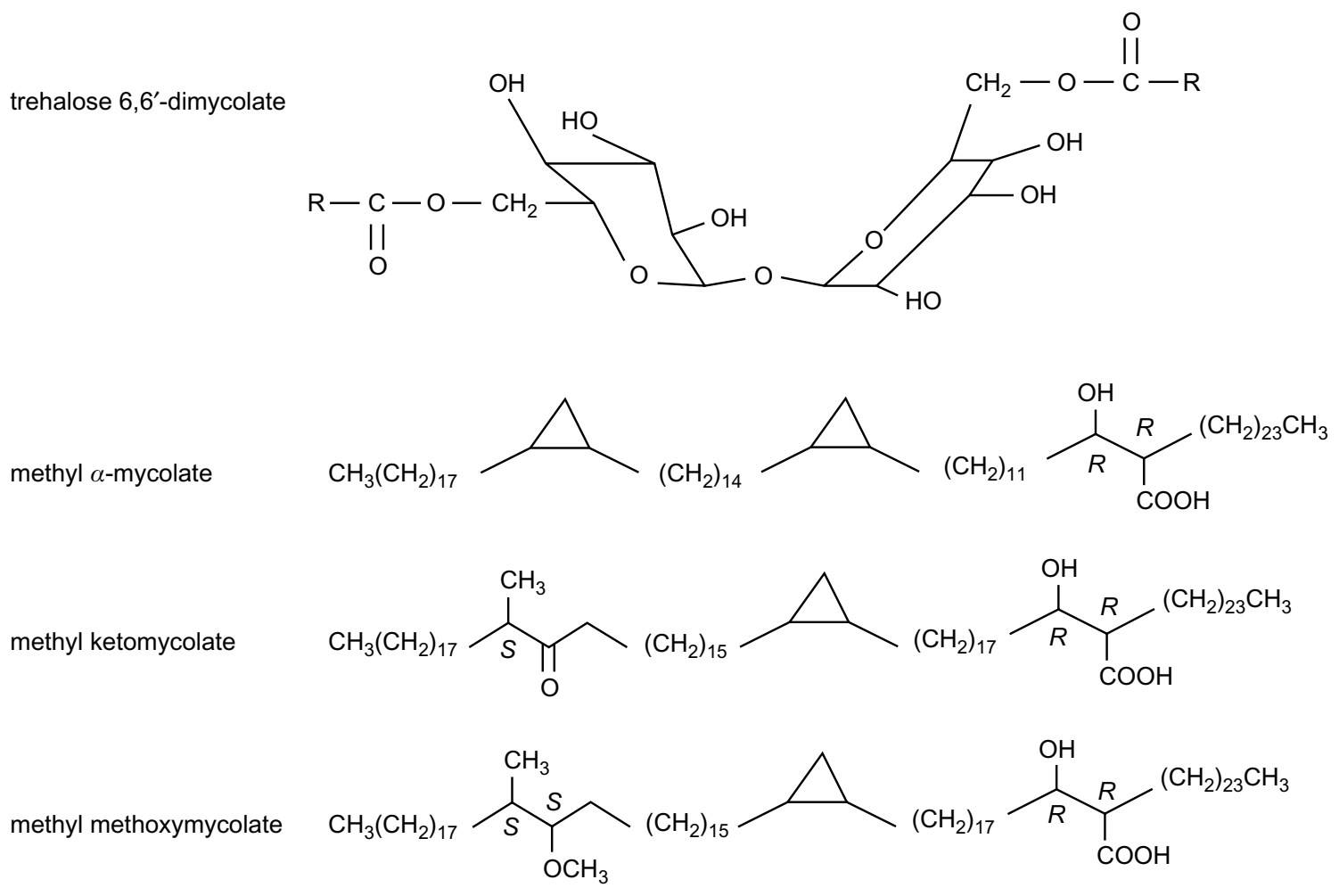

Fig. 1. Chemical structures of four mycolate derivatives. 


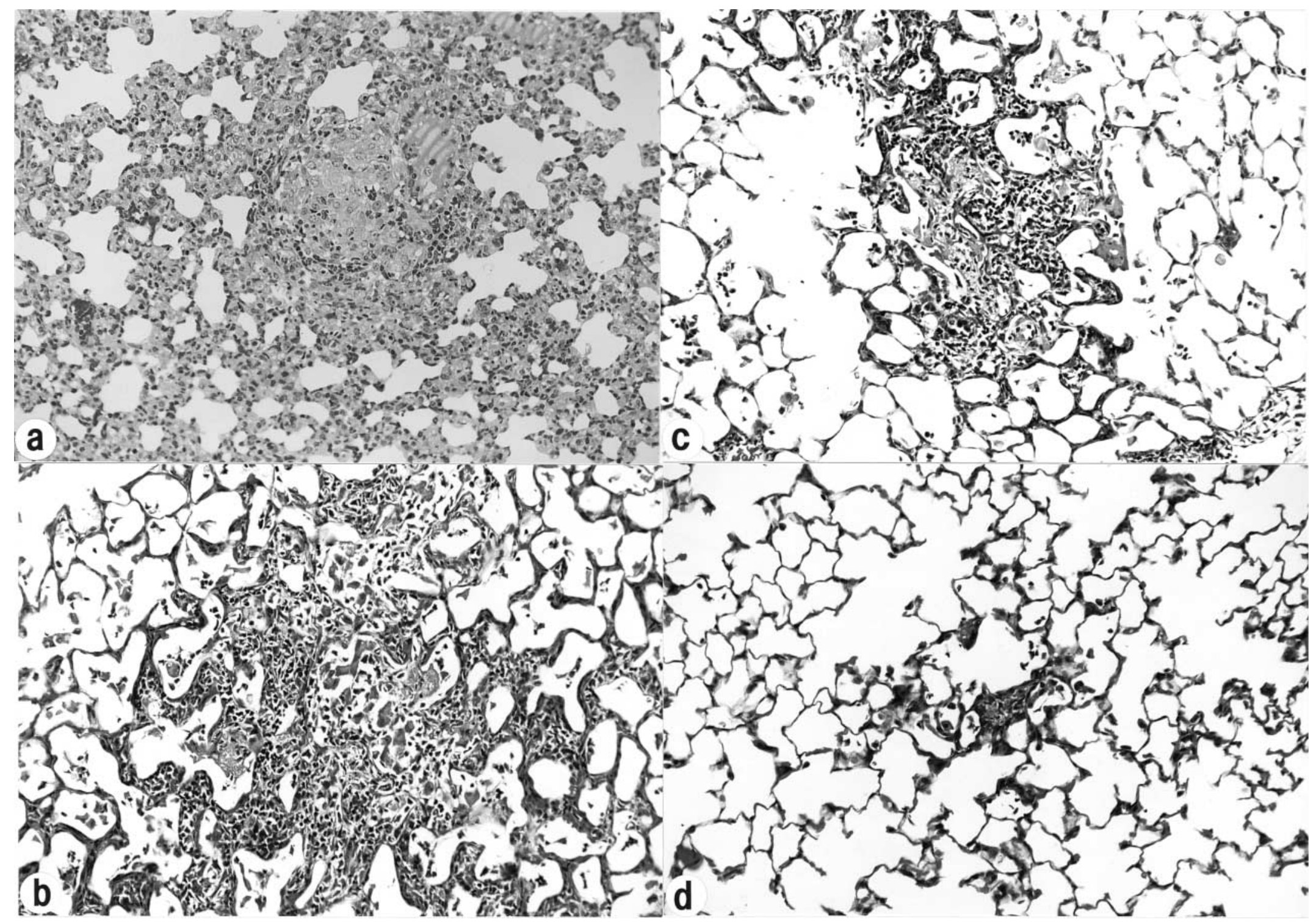

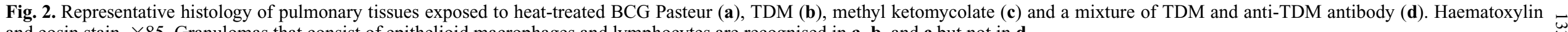
and eosin stain, $\times 85$. Granulomas that consist of epithelioid macrophages and lymphocytes are recognised in $\mathbf{a}, \mathbf{b}$, and $\mathbf{c}$ but not in $\mathbf{d}$ 
amplified through 35 cycles in a programmable thermal cycler (Perkin-Elmer Cetus) with a three-step cycle of denaturation for $2 \mathrm{~min}$ at $94^{\circ} \mathrm{C}$, annealing for $1.75 \mathrm{~min}$ at $60^{\circ} \mathrm{C}$ and extension for $2.5 \mathrm{~min}$ at $72^{\circ} \mathrm{C}$. The amplification products (541 and $320 \mathrm{bp}$ ) were analysed by electrophoresis through an agarose $2.0 \%$ gel with a Tris-borate-EDTA buffer system and visualised by fluorescence after ethidium bromide staining [7,9].

\section{Statistical analysis}

All values were expressed as means and SEM and compared by Student's $t$ test. For all statistical analyses, differences at $\mathrm{p}<0.01$ were considered significant.

\section{Results}

\section{Histopathology of the lungs}

When heat-treated BCG Pasteur was administered aerially, pulmonary granulomatous lesions without central necrosis developed in all five guinea-pigs (Fig. 2a), but autoclaved BCG Pasteur did not induce pulmonary granulomatous lesions. Of the four mycolate derivatives, TDM, methyl ketomycolate, methyl mathoxymycolate and methyl $\alpha$-mycolate, only TDM and methyl ketomycolate induced pulmonary granulomatous lesions $(p<0.01)$ (Figs. $2 b$ and $c)$. The granulomatous lesions consisted of lymphocytes and epithelioid macrophages. When the mixture of TDM and anti-TDM antibody was introduced aerially,

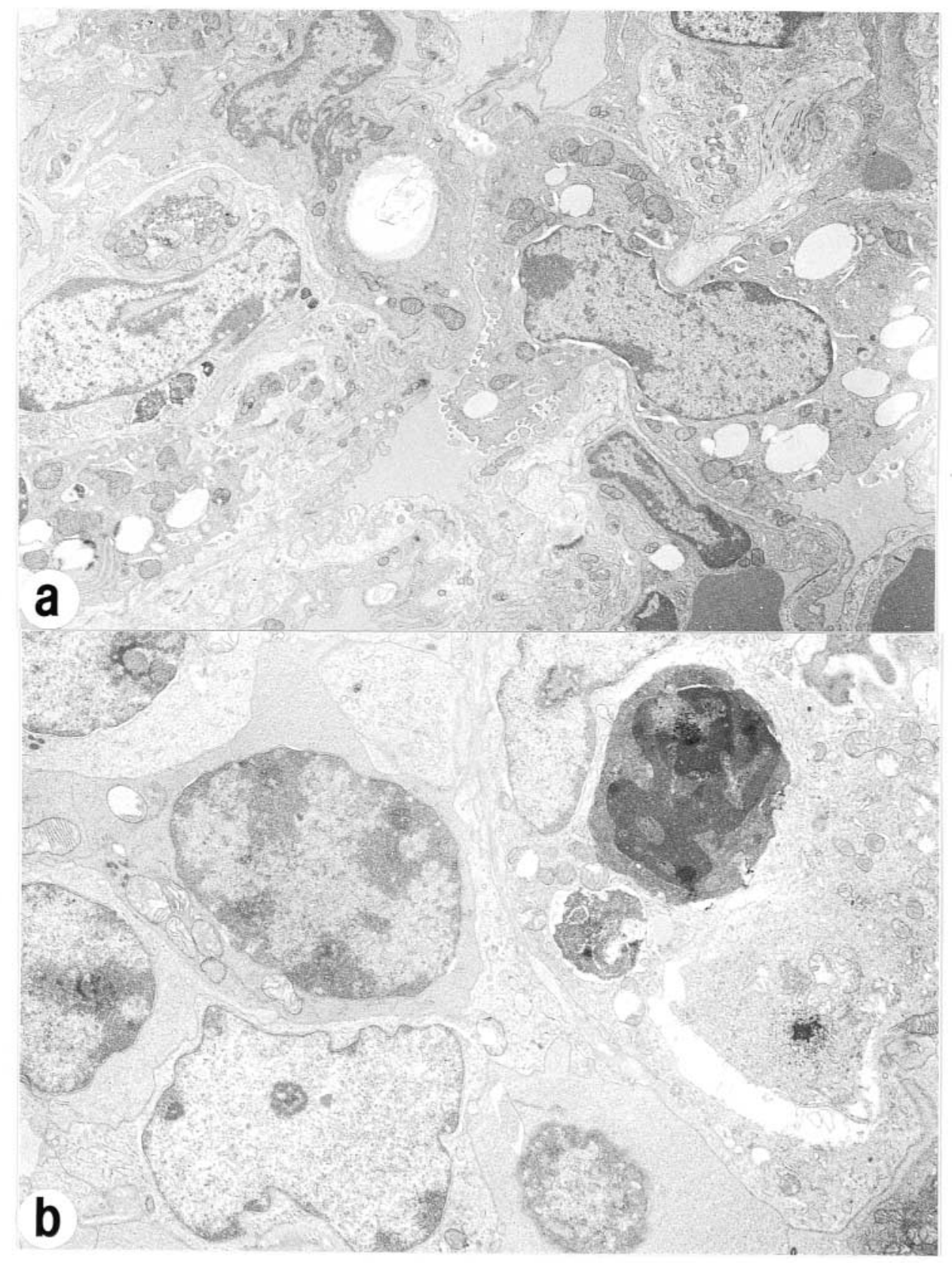

Fig. 3. Electron micrographs of pulmonary granulomas from a BALB/c mouse exposed to aerosols of (a) TDM ( $\times 4900)$ or $(\mathbf{b})$ methyl ketomycolate $(\times 5900)$. Several epithelioid macrophages and lymphocytes are shown. 


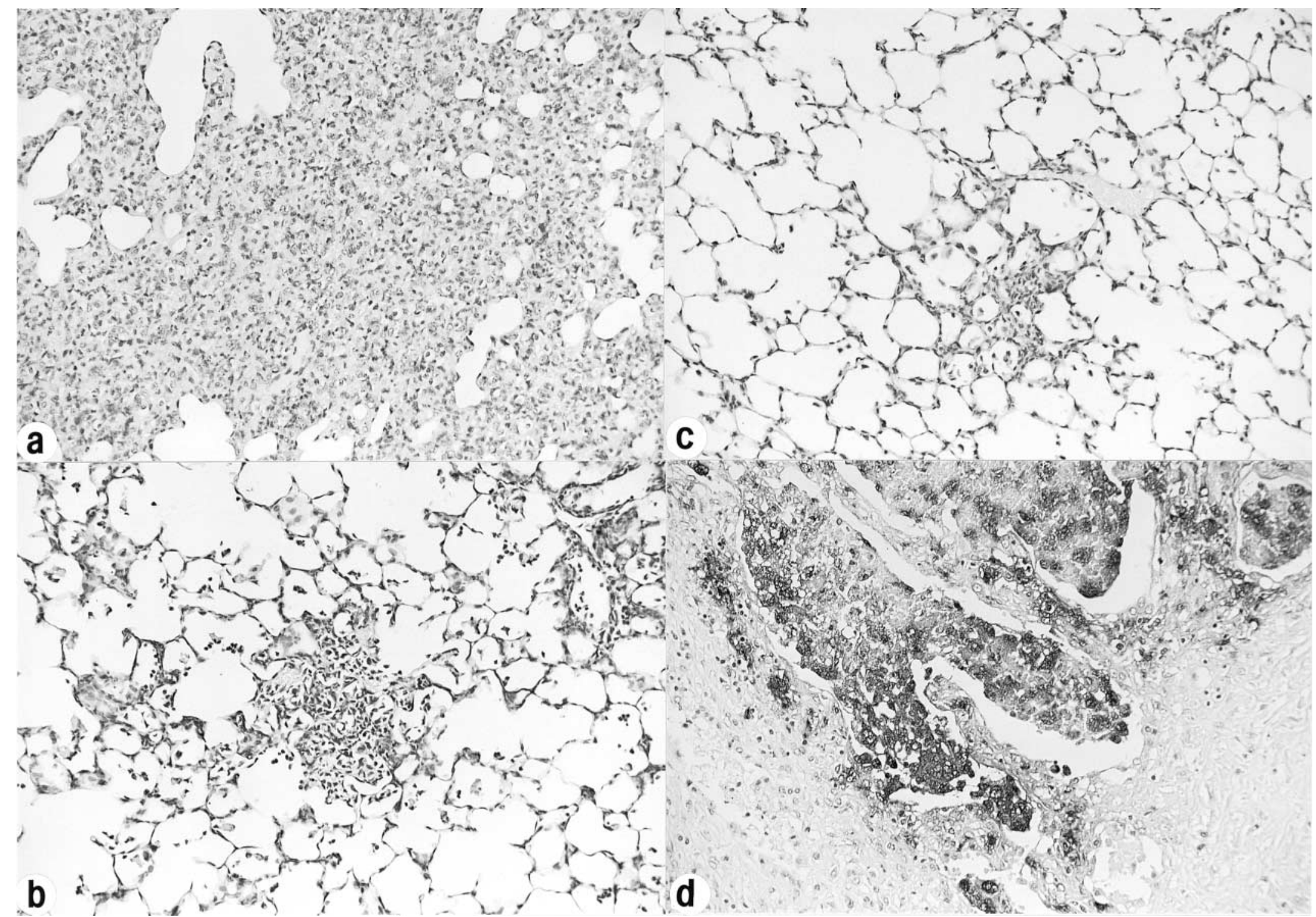

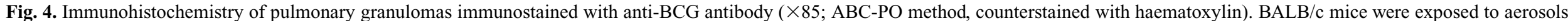
containing (a) heat-treated BCG Pasteur bacilli, (b) TDM, (c) methyl ketomycolate and (d) live BCG Pasteur bacilli. Only epithelioid macrophages from mice exposed to aerosols of live BCG Pasteur were immunostained intensely with anti-BCG (d). 
granulomas were hardly recognised (Fig. 2d). Langhans-type multinucleate giant cells were not observed.

Similar pathology was observed by electron microscopy. Discrete and small granuloma formation was noted in both TDM- and methyl ketomycolate-treated lung tissues. The granulomatous lesions consisted of epithelioid macrophages of varying sizes, lymphocytes and small vessels. No eosinophil, basophil or plasma cells were observed in these lesions (Fig. 3a).

Immunohistochemically, the antigens (cell wall components) recognised by anti-BCG antibody were present in epithelioid macrophages of the granulomatous lesions when live BCG Pasteur was used (Fig. 4d), but not in epithelioid macrophages when heat- and autoclave-treated BCG Pasteur, TDM and methyl ketomycolate were introduced into the lungs of guinea-pigs (Fig. 4a, b and c).

\section{$P C R$}

Large DNA fragments were not obtained from the heattreated and autoclaved BCG Pasteur. M. tuberculosisspecific $19-\mathrm{kDa}$ antigen gene fragments and IS6110related DNA fragments were detected by PCR in live BCG Pasteur, but not detected in heat-treated and autoclaved $M$. bovis BCG (Fig. 5).

\section{Discussion}

Granulomas were induced successfully in the lungs when killed BCG Pasteur bacilli, purified TDM and methyl ketomycolate were introduced aerially in an inhalation exposure apparatus. Intravenous injection of TDM and adjuvant is the preferred method for inducing granulomas efficiently $[2,5,6]$. This study examined whether TDM as one of the causative agents of Mycobacterium-induced granulomas induces similar granulomatous lesions after inhalation exposure.
TDM is a well-known, toxic glycolipid in $M$. tuberculosis. It is also reported that TDM derived from Nocardia and Rhodococcus possesses granulomaforming activity $[5,13]$. In the present study, methyl ketomycolate induced pulmonary granulomas, but methyl $\alpha$-mycolate and methyl methoxymycolate did not. The molecular basis for the similar granulomainducing activity of TDM and methyl ketomycolate is unknown because there is little structural similarity between them. Further study will be required to clarify this discrepancy.

Anti-BCG antibody reacted with granulomas induced by live $M$. bovis BCG Pasteur but did not react with granulomas induced by heat-treated and autoclaved BCG Pasteur. Mycobacterial cell wall components are destroyed by heat treatment and autoclaving. This may explain non-reactivity with granulomas induced by heat-treated and autoclaved BCG. The anti-BCG antibody also did not react with TDM and methyl ketomycolate, as evidenced by the absence of immunostaining in granulomas induced by them.

It is evident that mycobacterial cell wall components induce pulmonary granulomas because Mycobacterium-specific DNA fragments were not detected in granulomatous lesions induced by heat-treated BCG Pasteur as assessed by PCR. Autoclaved BCG Pasteur and heat-treated BCG Pasteur did not contain mycobacterial DNA as assessed by gel electrophoresis. Pulmonary granulomatous lesions without central necrosis developed from the introduction of heattreated BCG Pasteur, but autoclaved BCG Pasteur did not induce pulmonary granulomatous lesions. Heat treatment at $95^{\circ} \mathrm{C}$ for $30 \mathrm{~min}$ does not affect granulomatogenic substances, but autoclaving at $121^{\circ} \mathrm{C}$ for 30 min may destroy cell wall components completely. Heat- treated H37Rv also induced pulmonary granulomas without necrosis (data not shown).

TDM is a potent granulomatogenic substance reported

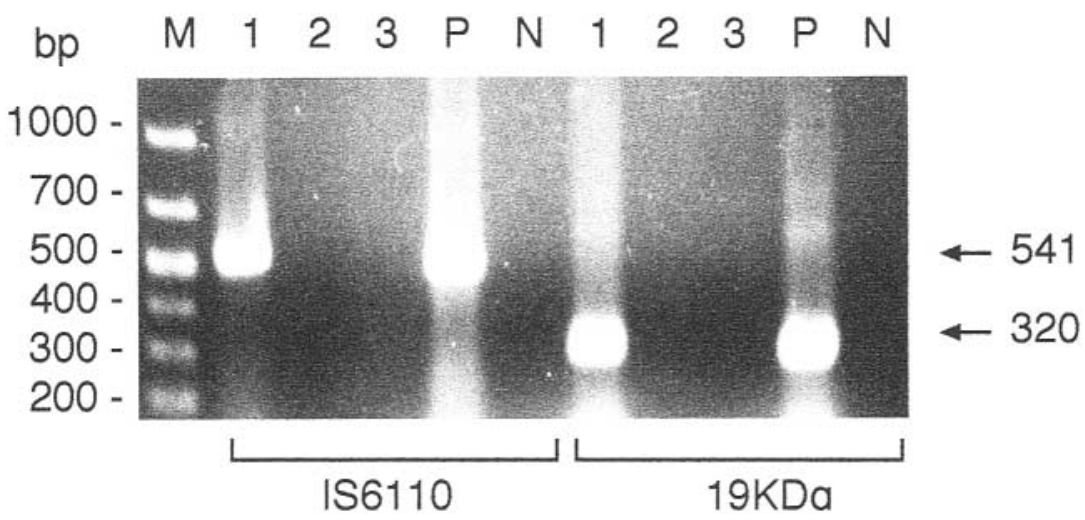

Fig. 5. PCR products of $19-\mathrm{kDa}$ antigen-specific and IS6110 amplification separated in agarose $2 \%$ gel. M, size marker; lane 1, DNA from BCG Pasteur bacilli; 2, DNA from heat-treated BCG Pasteur bacilli; 3, DNA from autoclaved BCG Pasteur bacilli; P, DNA from M. tuberculosis H37Rv; N, negative control (no DNA). The 19-kDa antigen-specific and IS6110-specific amplified bands ( $320 \mathrm{bp}$ and $541 \mathrm{bp})$ are not present in lanes 2 and 3. 
by many studies [2-6]. When antibody to TDM was added to TDM before exposure of guinea-pigs to aerosols, the mixture abolished granuloma formation significantly. This antibody blocked the granulomatogenic action by binding to TDM. Methyl ketomycolate was also granolomatogenic by inhalation exposure. Thus, methyl ketomycolate is a granulomatogenic candidate that may be important in the development of human tuberculosis.

The granulomas induced by heat-treated BCG Pasteur, TDM and methyl ketomycolate consist of lymphocytes and epithelioid macrophages. This granuloma is different from hypersensitivity pneumonitis, which consists of plasma cells and basophils as well as lymphocytes and epithelioid macrophages $[14,15]$. It is reported that TDM induces foreign body- and hypersensitivity-type granulomas in mice [16]. According to these published criteria, the granulomas formed in the present study were of the foreign bodytype.

In summary, heat-treated BCG Pasteur, TDM and methyl ketomycolate were shown to induce pulmonary granulomas after inhalation exposure. TDM and methyl ketomycolate may play an important role in the pathogenesis of tuberculosis.

This study was supported in part by an International Collaborative Study Grant awarded to I. S. from the Ministry of Health, Labor and Welfare, Japan. We thank Professor Emeritus I. Yano for useful suggestions. Part of this work was presented at the Annual Meeting of the Japanese Society of Sarcoidosis and related granulomatous diseases, Oita, Japan, in 2000.

\section{References}

1. Garay SM. Pulmonary tuberculosis. In: Rom WN, Garay SM (eds) Tuberculosis. Boston, Little, Brown and Company. 1996: 373-412.

2. Behling CA, Perez RL, Kidd MR, Staton GW, Hunter RL. Induction of pulmonary granulomas, macrophage procoagulant activity, and tumor necrosis factor-alpha by trehalose glycolipids. Ann Clin Lab Sci 1993; 23: 256-266.

3. Yamamoto K, Kakinuma M, Kato K, Okuyama H, Azuma I. Relationship of anti- tuberculous protection to lung granuloma produced by intravenous injection of synthetic 6-O-mycoloyl-Nacetylmuramyl-L-alanyl-D-isoglutamine with or without specific antigens. Immunology 1980; 40: 557-564.

4. Bekierkunst A, Levij IS, Yarkoni E, Vilkas E, Adam A, Lederer E. Granuloma formation induced in mice by chemically defined mycobacterial fractions. J Bacteriol 1969; 100: 95-102.

5. Natsuhara Y, Yoshinaga J, Shogaki T et al. Granuloma-forming activity and antitumor activity of newly isolated mycolyl glycolipid from Rhodococcus terrae 70012 (Rt. GM-2). Microbiol Immunol 1990; 34: 45-53.

6. Sakurai T, Saiki I, Ishida H, Takeda K, Azuma I. Lethal toxicity and adjuvant activities of synthetic TDM and its related compounds in mice. Vaccine 1989; 7: 269-274.

7. Sugawara I, Yamada H, Kaneko H, Mizuno S, Takeda K, Akira S. Role of interleukin-18 in mycobacterial infection in IL-18gene disrupted mice. Infect Immun 1999; 67: 2585-2589.

8. Sugawara I, Yamada H, Mizuno S, Iwakura Y. IL-4 is required for defense against mycobacterial infection. Microbiol Immunol 2000; 44: 971-979.

9. Yamada H, Mizumo S, Horai R, Iwakura Y, Sugawara I. Protective role of interleukin-1 in mycobacterial infection in interleukin-1 alpha/beta double-knockout mice. Lab Invest 2000; 80: $759-767$.

10. Nakamura H, Morishita Y, Sugawara I et al. Ultrastructural localization of antigens recognized by 5D-4 monoclonal antibody reactive with islets of Langerhans. J Clin Electron Microsc 1990; 23: 393-398.

11. Sugawara I, Yamada H, Kazumi $\mathrm{Y}$ et al. Induction of granulomas in interferon- $\gamma$ gene-disrupted mice by avirulent but not by virulent strains of Mycobacterium tuberculosis. $J$ Med Microbiol 1998; 47: 871-877.

12. Hsu S-M, Raine L, Fanger H. Use of avidin-biotin-peroxidase complex $(\mathrm{ABC})$ in immunoperoxidase techniques: a comparison between $\mathrm{ABC}$ and unlabeled antibody (PAP) procedures. J Histochem Cytochem 1981; 29: 577-580.

13. Han Y, Kawada N, Yano I. Granuloma formation and in vitro macrophage activation in mice by mycoloyl glycolipids from Nocardia asteroides and related taxa. Osaka City Med J 1998; 44: 201-217.

14. Schuyler M, Gott K, Haley P. Experimental murine hypersensitivity pneumonitis. Cell Immunol 1991; 136: 303-317.

15. Takizawa $\mathrm{H}$, Ohta $\mathrm{K}$, Horiuchi $\mathrm{T}$ et al. Hypersensitivity pneumonitis in athymic nude mice. Additional evidence of $\mathrm{T}$ cell dependency. Am Rev Respir Dis 1992; 146: 479-484.

16. Yamagami H, Matsumoto $\mathrm{T}$, Fujiwara $\mathrm{N}$ et al. Trehalose 6,6'dimycolate (cord factor) of Mycobacterium tuberculosis induces foreign-body- and hypersensitivity-type granulomas in mice. Infect Immun 2001; 69: 810-815. 